\title{
A quantitative analysis of forest fragmentation in Los Tuxtlas, southeast Mexico: patterns and implications for conservation
}

\author{
Un análisis cuantitativo de la fragmentación de la selva de Los Tuxtlas en el sudeste de \\ México: patrones e implicaciones para la conservación
}

EDUARDO MENDOZA ${ }^{1}$, JOHN FAY ${ }^{2} \&$ RODOLFO DIRZO ${ }^{1,3}$

\author{
${ }^{1}$ Instituto de Ecología, Departamento de Ecología Evolutiva, UNAM, Apartado Postal 70-275, \\ México 04510, Distrito Federal; e-mail: emr_999@yahoo.com.mx \\ ${ }^{2}$ Center for Conservation Biology, Stanford University, Stanford, California 94305, USA \\ ${ }^{3}$ Current address: Department of Biological Sciences, Stanford University, Stanford, California 94305, USA
}

\begin{abstract}
Habitat loss is a critical threat to tropical biodiversity and its quantification constitutes a central conservation issue. Typically, assessments have been based on deforestation rates statistics. However, this overlooks the effects brought about by the spatial reconfiguration of the remaining habitat: fragmentation. We present an analysis of fragmentation in a Neotropical site aimed at: (a) devising a protocol for its quantification, (b) using such protocol to provide insights on the ecological consequences of fragmentation, (c) exploring its applicability to address the hypothesis that forest size-inequality decreases with elevation, an indicator of habitat accessibility. We applied the Gini coefficient $(\mathrm{G})$ and the Lorenz curve to analyze fragment-size variation using a satellite-generated map. We also estimated edge effect, fragment shape and isolation. Remaining forest includes 1,005 fragments, ranging from 0.5 to 9.356 ha (median $=0.89$ ). Size inequality was very high $(\mathrm{G}=0.928)$, producing a flattened Lorenz curve. Forty percent of the fragments did not maintain an area free of a 30-m edge effect, and larger fragments showed a marked deviation from ideal circular forms. Eighty-four percent of the fragments lay further than $500 \mathrm{~m}$ from the largest forest tract and their size decreased with distance. Fragment size distribution changed with altitude: the Gini coefficient was lowest and forest coverage was greatest at the highest altitude, but inequality peaked at an intermediate elevation. Given the current pace of habitat deterioration, application of similar analyses may improve global assessments of tropical ecosystems and their perspectives for biodiversity conservation.
\end{abstract}

Key words: edge effect, fragment shape, Gini coefficient, Lorenz curve, tropical rain forest.

\section{RESUMEN}

La destrucción del hábitat es la principal amenaza para la biodiversidad tropical, por lo que su cuantificación constituye un aspecto central para la biología de la conservación. Usualmente, esta cuantificación se basa en el cálculo de las tasas de deforestación, ignorando los efectos derivados de la reconfiguración espacial del hábitat remanente postdeforestación: la fragmentación. Aquí presentamos un análisis de la fragmentación en un sitio Neotropical para: (a) proponer un protocolo para su cuantificación; (b) utilizar tal protocolo para explorar las consecuencias ecológicas de la fragmentación; y (c) explorar su aplicación para evaluar la hipótesis de que la heterogeneidad de tamaños de los fragmentos disminuye con la elevación (indicativo de la accesibilidad del hábitat). Calculamos el coeficiente de Gini y la curva de Lorenz para analizar la desigualdad de tamaños de los fragmentos, utilizando un mapa generado con una imagen de satélite; además evaluamos el efecto de borde, la forma de los fragmentos y su grado de aislamiento. Encontramos que el bosque remanente incluye 1.005 fragmentos entre 0,5 y 9,356 ha (mediana $=0,89$ ). La desigualdad de tamaños fue considerable $(\mathrm{G}=0,928)$, con una curva de Lorenz muy abatida. El $40 \%$ de los fragmentos no tuvo un área libre de un efecto de borde de $30 \mathrm{~m}$ de ancho; los fragmentos más grandes mostraron un desvío considerable con respecto a la forma circular ideal. El $84 \%$ de los fragmentos estuvo aislado, ubicándose más allá de $500 \mathrm{~m}$ de distancia del parche más grande de bosque y su tamaño disminuyó con la distancia. La distribución de tamaños de los fragmentos varió con la elevación: el coeficiente de Gini fue menor y la cobertura relativa de bosque fue mayor en la elevación más grande, pero la desigualdad fue máxima en una elevación intermedia. Proponemos que, en vista de los ritmos actuales de deterioro del hábitat, la aplicación de análisis similares puede mejorar nuestras evaluaciones del estado de conservación de los ecosistemas tropicales y las perspectivas para la conservación de la biodiversidad.

Palabras clave: efecto de borde, tamaño de fragmento, coeficiente de Gini, curva de Lorenz, selva tropical lluviosa. 


\section{INTRODUCTION}

Habitat loss brought about by anthropogenic activities is widely recognized as the most conspicuous and pervasive threat to biodiversity in the tropics (Laurance \& Bierregaard 1997). Upon recognition of its deleterious effects, including species extinction, local and global climate change, soil erosion, water pollution, and the loss of various environmental services (Malhi \& Grace 2000, Lawton et al. 2001), several initiatives have been developed to estimate its global magnitude (e.g., WRI 1990, FAO 1993, 2001, Achard et al. 2002). These assessments have produced valuable insights into the general trends of tropical forest area loss. However, the estimates they provide remain highly variable and are sometimes inconsistent (WRI 1990, FAO 1993, 2001, Achard et al. 2002, Kaiser 2002). On the other hand, and of more ecological significance, global assessments of net cover change and their coarse spatial resolution downplay the variety of complex repercussions arising from the spatial reconfiguration of the remnant habitat after deforestation (Vitousek et al. 1997, Borges 2000, Dirzo 2001). Indeed, over the last few decades, habitat fragmentation -the breaking apart and isolation of formerly continuous forest (Saunders et al. 1991)- has been found to have a number of negative ecological effects (Turner 1996, Laurance et al. 2002, but see Fahrig 2003). Traditionally, the effects of fragmentation have been considered in terms of the impact of the size of the remaining forest patches (Laurance et al. 2002). However, increasing evidence shows that such effects may also stem from the spatial distribution (e.g., degree of isolation, location along altitudinal gradients) and shape (e.g. edge/area ratio) of the remaining forest patches resulting from current land use patterns (Borges 2000, Silva \& Tabarelli 2000, Laurance et al. 2002).

These ecological findings, in conjunction with the global occurrence of habitat fragmentation make its quantification a topic that deserves further attention than it has had hitherto. Local assessments of forest loss incorporating quantitative descriptions of fragmentation may be valuable tools for local conservation and management planning but also for the development of standardized descriptors of habitat "quality". Such local assessments may subsequently be used as baselines to provide more realistic local and global assessments of the threats to tropical biodiversity resulting from current land use patterns (Skole \& Tucker 1993, Ranta et al. 1998, Sánchez-Azofeifa et al. 2001).

Though a number of parameters to describe landscape fragmentation have been already proposed in the scientific literature (Gustafson 1998), we present a novel, complementary approach based on the application of the Gini coefficient and the Lorenz curve. These analytical tools were originally developed for the study of economic wealth distribution and income inequality (Weiner 1986). However, they have proved to be very useful to describe an ample array of ecological situations where a hierarchical organization develops, ranging from the skewed distributions of individual size in plant populations under strong competition (Weiner \& Solbrig 1984, Weiner 1986, Weiner \& Thomas 1986), to the strength of edge effects in plant species composition in forests (Matlack 1994) or size inequalities among parts (shoots) within plants (Larson \& Whitham 1997). The increasing familiarity of ecologists with such tools may permit their use in quantification of habitat fragmentation, where a hierarchical distribution of patch sizes is likely to develop. In this case the Lorenz curve may provide a standardized graphical representation of area distribution among fragments whose form, in contrast to histograms, is not influenced by class sizes and number. In addition, information contained in the Lorenz curve can be summarized in a single parameter, the Gini coefficient, that can be readily amenable for comparison and statistical analysis.

To our knowledge, no attempt has been made to quantitatively describe habitat fragmentation using these tools. In this study we combine the use of such techniques with other quantitative descriptors of the spatial configuration and shape of forest fragments to assess the conservation status of a Neotropical site. Specifically, this study focuses on a rain forest site of relevance for the Neotropics at large. The concerned study site, Los Tuxtlas (state of Veracruz, México), constitutes the northernmost limit of the distribution of this ecosystem in the Americas (Dirzo \& Miranda 1991a) and is one of most studied sites in the Neotropics (see 
González et al. 1997). We addressed four particular questions: (i) how is remaining forest area distributed among fragments? (ii) to what extent the incorporation of edge effect may reduce effective fragment area and number? (iii) to what extent the ratio area/perimeter of fragments deviates from the corresponding ratio of circular fragments (which minimize area exposure) of the same size? (iv) how are forest fragments distributed in space as a function of distance from the largest tract of remaining forest? In addition, we developed an exercise to test the applicability of the Gini coefficient and the Lorenz curve by comparing such parameters across a deliberately defined stratification of the terrain in terms of altitudinal bands. In particular we evaluated the expectation that the value of the Gini coefficient (and its graphical representation, the Lorenz curve) would be lower, indicating the lowest inequality, as elevation increases, given that elevation is an indicator of land inaccessibility and thus susceptibility to human influence. A test of this hypothesis is relevant for sites that, like Los Tuxtlas, include a topographic/elevation gradient.

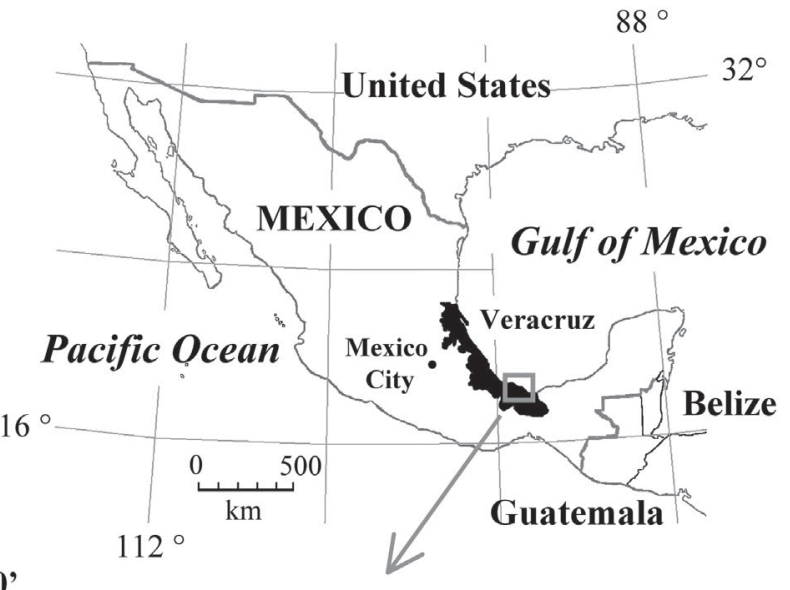

$95^{\circ} 10^{\prime}$

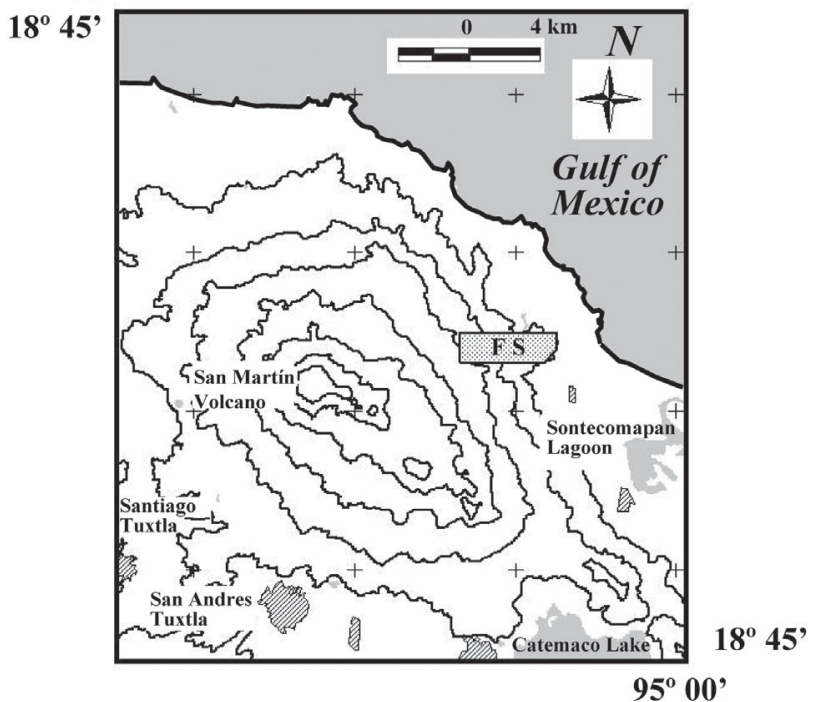

Fig. 1: Location of the study area in southeast Mexico and UNAM's field station (FS). The isolines represent 200-m elevation bands, starting from $200 \mathrm{~m}$ (the outermost, adjacent to the coastline) till $1,400 \mathrm{~m}$ (the innermost). Shaded areas represent major human settlements.

Ubicación del área de estudio en el sudeste de México y de la estación biológica de la UNAM (FS). Las isolíneas indican intervalos de $200 \mathrm{~m}$ en altitud, a partir de $\operatorname{los} 200 \mathrm{~m}$ y hasta $\operatorname{los} 1.400 \mathrm{~m}$. Las zonas con achurado representan los poblados más grandes. 


\section{MATERIAL AND METHODS}

\section{Study area}

This study encompasses an area of 83,644 ha of continental land that includes the northernmost portion of the Sierra de Los Tuxtlas, in southern Veracruz, Mexico (Fig. 1). The Sierra de Los Tuxtlas is a diagonal mountainous range composed of a series of volcanic cones running in a NW-SE direction, the most conspicuous of which are the San Martín (included in this study) and the Santa Marta (a large tract of forest located towards the southeast of the study site), both with an altitude close to $1.650 \mathrm{~m}$ (Dirzo \& García 1992). These volcanoes represent the northwestern and southeastern extremes, respectively, of the Sierra de Los Tuxtlas. Between such volcanoes lies the Catemaco Lake, the fourth largest in the country.

Average temperature ranges between 24 and $26{ }^{\circ} \mathrm{C}$ in most of the study area, with lower values (20-22 $\left.{ }^{\circ} \mathrm{C}\right)$ at higher altitudes. Annual precipitation ranges between 3,000 and 4,500 $\mathrm{mm}$ but may be even higher in some sectors of the area (Soto \& Gama 1997). Originally, the predominant vegetation type was lowland tropical rain forest with marked altitudinal variants, including mixed pine-oak patches, cloud forest and elfin forest. Mangrove vegetation is associated to the Sontecomapan lagoon located on the eastern portion of the study area (Fig.1) (Dirzo et al. 1997, Ibarra-Manríquez et al. 1997). Additional vegetation variants are related to edaphic factors such as soil depth and the presence of lava outcrops (Dirzo et al. 1997, Ibarra-Manríquez et al. 1997). For a detailed description of the area see Dirzo et al. (1997).

Los Tuxtlas has a long history of exposure to human activities, in particular those related to cattle ranching. This dates from the first quarter of the sixteenth century, but it significantly expanded during the decade of the 1950's, when it began to experience an accelerated growth, marking the start of an extensive transformation of the natural habitats in the region (Guevara et al. 1997).

\section{Image classification and generation of forest map}

To generate the forest map of our study area we used a previously geo-referenced sub-scene from a yr 2000 Landsat-7 image (obtained from the Institute of Geography, UNAM), with six bands and a pixel size of $30 \times 30 \mathrm{~m}$. For the classification of this image we conducted a supervised classification using the IDRISI 32 (Clark Labs, The Idrisi Project) imageprocessing protocol. We selected representative areas of the following land-cover classes as training fields: (1) water bodies, (2) mature forest, (3) secondary forest, (4) mangrove, (5) pasture and agriculture and (6) barren soil. In some cases we used subdivisions of the main land-cover classes to deal with more homogeneous land-cover subcategories. Selection of the training fields was based on the visual interpretation of color composites, digital aerial photography (yr 2000) and field work.

Previous to the classification we applied the SEPSIG option of IDRISI 32 to the six-band image and to a vegetation index (the NDVI), in order to select the subset of bands with the best potential to separate land cover categories, and to create final signature files for each land cover type (Eastman 1999). We used the signatures to carry out a maximum likelihood classification of the pixels (MAXLIKE option of IDRISI 32). We repeated this process until we found a satisfactory match between pixel assignation to a given forest category and visual inspection of digital and analog aerial photography (2000 and 1991, respectively). Given that the main concern of this study was mature forest area, we aggregated all non-forest categories (except water bodies) thus generating a map with just three elements: mature forest, non-forest and water. The resulting map was then subjected to an accuracy assessment.

For such an assessment we physically located 48 ground-truthing points scattered throughout the study area (30 in mature forest, 14 in secondary forest and four in water) and employed the ERRMAT option of IDRISI 32 to assess the agreement between field information and land-cover designation in our map (Eastman 1999). To have an additional indicator of the accuracy of the classification, we obtained the Kappa Index of Agreement in general, and for each land-cover category in particular (Eastman 1999). This index compares the proportion of correctly classified pixels (based on ground-truthing data) against 
the proportion of pixels expected to fall in the correct class just by chance. Possible values of the index range between zero (no difference with the expected random pattern) to one (100 $\%$ accuracy) (Congalton \& Mead 1983).

As a final step of this phase of the work we excluded all classified forest fragments with an area equal to or smaller than $3,600 \mathrm{~m}^{2}$ (4 pixels), based on two criteria: (a) any fragment equal to or smaller than $3,600 \mathrm{~m}^{2}$ is completely influenced by edge effects (see below) and (b) individual pixels classified as forest frequently represent isolated trees. The final map (raster file) was transformed to a vector format using IDRISI 32 (Clark Labs, The Idrisi Project) to facilitate subsequent manipulation.

\section{Distribution of remnant forest area among fragments}

In order to describe patterns of variation in fragment size we employed the Lorenz curve and the Gini coefficient (Weiner \& Solbrig 1984, Weiner 1986). The Lorenz curve allows a visual inspection of the departure of fragments from perfect equality (meaning in this case that all fragments have the same forest area), as represented by a diagonal that connects the $(0$ $0)$ and (100 -100) coordinates of a fragmentsarea plot. Such a procedure involves the graphical representation of the cumulative percentage of area against the cumulative percentage of the "population" of forest fragments ranked in an upward sequence according to their size. Associated to this, the Gini coefficient provides a quantitative estimation of the departure from perfect equality. The Gini coefficient has a minimum value of cero when all the individuals (i.e., fragments in this case) contribute in the same relative magnitude to the total population "wealth" (i.e., forest area) and a theoretical maximum of 1 when all but one of the individuals (fragments) have a 0 contribution to the total population wealth (Slack \& Rodrigue 2002). The Gini coefficient can readily be calculated as follows (Slack \& Rodrigue 2002):

$$
G=\left|1-\sum_{i=0}^{N}\left(\sigma Y_{i-1}+\sigma Y_{i}\right)\left(\sigma X_{i}-\sigma X_{i-1}\right)\right|
$$

where $\mathrm{N}=$ number of fragments, $\mathrm{Y}_{\mathrm{i}}=$ observed proportional area of each fragment, $\mathrm{X}_{\mathrm{i}}=$ expected proportional area of each fragment if area were distributed equally, $\sigma \mathrm{Y}=$ accumulated proportions of $\mathrm{Y}$ values and $\sigma \mathrm{X}=$ accumulated proportions of $X$ values. An estimate of the standard deviation for the Gini coefficient was generated using the DAD 4.2 software following Duclos et al. (2002).

\section{Analysis of edge effect}

It is known that the penetration distance of edge effects varies widely depending on the variable under examination. In addition, edge effect intensity varies as a consequence of edge age and the type of surrounding matrix (Laurance et al. 2002). Such effects of edge will determine effective fragment size and number. As a conservative approach, we took advantage of the existence of a recent study carried out in our study site, in which the variation in temperature and relative humidity were systematically measured at $1-\mathrm{m}$ distances established on transects moving from the edge towards the interior of a series of fragments (Ruiz 2003). Several transects were used per fragment, including a range of fragment sizes. The large data set derived from these transects allowed for best-fit models of distance versus temperature/humidity to be performed. Field data for this study were gathered in 2001, only one year apart from the date of the image we used for the present study. This analysis detected an asymptote in the response of these variables at $30 \mathrm{~m}$. Nevertheless, in order to explore the possibility that the penetration distance for other variables would be greater, we developed an additional exercise of exploring the changes in the number of fragments and their variation in size, using distances of 60 and $100 \mathrm{~m}$.

Once we decided to use these three penetration distances we created a series of 30 , 60 , or $100 \mathrm{~m}$ inner strips, parallel to the edge of each fragment, with the ArcView 3.2a (ESRI) buffer option. We subsequently discounted the area of such strips from the area of each fragment using Patch Analyst 2.2 (Elkie et al. 1999). Through this process we obtained the core fragment area (i.e., fragment area free of edge effect). We analyzed relative frequencies of whole-area fragments (WF) and core-area fragments (CAF) using histograms in conjunction with the Lorenz curves. We also calculated the value of the Gini coefficient for 
the case of WF using the procedure described above

\section{Analysis of fragment shapes}

Although there exists a variety of indices to describe variation in fragment shape we decided to develop an approach that allowed a graphic description of the departure of forest fragment shapes from the ideal (for our purposes a circle, given that this shape maximizes the area/ perimeter ratio for any given area). For this purpose we calculated the area $(\mathrm{A}) /$ perimeter $(\mathrm{P})$ ratio for each of the observed fragments using Patch analyst 2.2 (Elkie et al. 1999) and we plotted those values on a chart with $\log$ of the area as the $\mathrm{X}$-axis and $\log$ of the $\mathrm{A} / \mathrm{P}$ ratios as the $\mathrm{Y}$-axis. We also calculated the A/P relationship for circular fragments with the same sizes as the observed fragments and plotted the resulting values onto the same graph. By comparing against the expected $\mathrm{A} / \mathrm{P}$ ratio of a circular fragment of the same area, we controlled for the effect of size variation. The line that results from connecting points representing $\mathrm{A} / \mathrm{P}$ ratios for circles of different size with the graph's origin defines the highest possible limit for $\mathrm{A} / \mathrm{P}$ values. Thus, an estimate of the departure of each fragment from its ideal form was obtained based on the distance between any observed data point and its corresponding value on the graph's diagonal. The resulting distances, in percentage, were grouped into the 25, 50, 75 and $100 \%$ quartiles, in order to compare departures among fragments of different class-sizes.

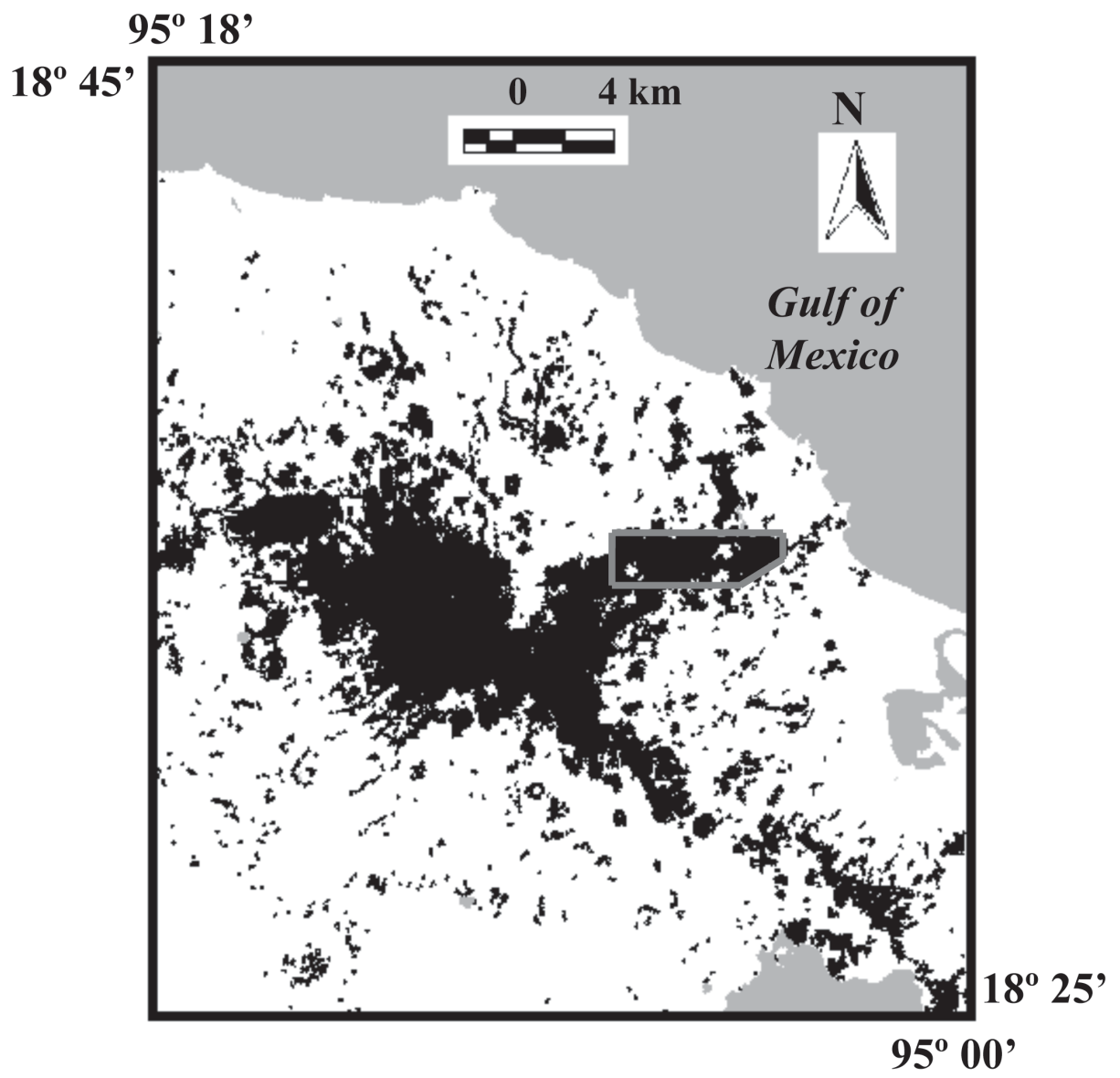

Fig. 2: Map depicting the study area and the current (i.e., year 2000) spatial distribution of forest fragments in Los Tuxtlas. The round-shaped forest mass to the center-left of the map corresponds to the San Martín volcano and the enclosed area to UNAM's field station.

Distribución espacial de los fragmentos de bosque en Los Tuxtlas. La porción redondeada de bosque al centro-izquierda del mapa corresponde al volcán San Martín y el área en el recuadro a la estación de la UNAM. 


\section{Fragment isolation}

In order to have an estimator of the level of isolation of the fragments with respect to the largest tract of remaining forest (see Fig. 2) we created a set of concentric bands (of 500-m width) around such fragment (using ArcView $3.2 \mathrm{a}$ utilities). The bands were irregular in shape, following the irregular edge of the largest fragment. We then quantified the number of fragments falling within each band. Large fragments lying on more than one distance interval were assigned to the first distance interval they contacted.

\section{Altitudinal variation of remnant forest and its distribution among fragments}

We explored the relationship between the spatial distribution of remnant forest and fragments with altitude employing a geo-referenced digital elevation model (DEM) of the zone (with a pixel size of $90 \times 90 \mathrm{~m}$ ) obtained from the Institute of Geography, UNAM, and our vegetation map. We used ArcView 3.2a (ESRI) to reclassify the DEM in five strata according to the following altitude intervals: 0-330, 331-660, 661-990, 9911,320 and $1,321-1,650 \mathrm{~m}$. After such reclassification we calculated the proportion of the area of study falling within each interval, excluding water bodies. We used ArcView 3.2a (ESRI) to overlay the area falling in each of the intervals with the forest map. After this we calculated the proportional coverage of forest for each altitude interval (assuming that the whole terrestrial area at each altitude interval could be potentially covered by forest). Additionally, we repeated the procedure described in the previous section, dealing with the analysis of distribution of forest area among fragments, in order to generate the Lorenz curves and the Gini coefficients for each one of the altitude intervals.

\section{RESULTS}

\section{Image classification and accuracy}

The error matrix produced an estimate of overall misclassification of $7 \%$ (range $0-14 \%$; $95 \%$ confidence interval). The main source of misclassification was inclusion of old secondary vegetation within the mature forest category (21\% commission error for secondary forest category). The values of the Kappa index of agreement for each cover category, using the forest map as the reference image, were 100, 100 and $72 \%$ for water, mature forest, and secondary forest, respectively. On the other hand, the corresponding values for the same categories using the ground-truthing map as the reference image were 100,75 , and $100 \%$, respectively. Therefore, there was a value of 87 $\%$ for the overall Kappa index of agreement; that is, we got $87 \%$ more accuracy in the classification, as compared with that expected by chance alone (see resulting forest map in Fig. 2). From the point of view of forest classification, inclusion of old secondary forest results in some level of over-estimation of remaining mature forest area.

\section{Distribution of remnant forest area among fragments}

Considering the entire study area, we found that both inequality parameters, the Lorenz curve and the Gini coefficient (Fig. 3A), are very close to the values that indicate maximal inequality. This implies an extreme contrast in the distribution of forest area among fragments, with the great majority of them having a very small area and just a few having a very large area. Specifically, ca. $90 \%$ of the fragment population only accumulates around $10 \%$ of the total forested area, while the remaining $10 \%$ of the fragments account for as much as $90 \%$ (Fig. 3A). This is consistent with the fact that one single fragment represents more than $60 \%$ of the existing forest area (cf. Fig. 2). Consequently, we observe (Fig. 3A) an almost complete occupation of the area lying on the sub-diagonal portion of the cumulative percentages plot (shaded area in Fig. $3 \mathrm{~A}$ ) in the case of the Lorenz curve, and a value very close to 1,0 in the case of the Gini coefficient (Fig. 3A).

\section{Edge effects}

The subtraction of strips of $30 \mathrm{~m}$ in width from the edge of each fragment (to simulate edge effects) produced several changes in the frequency-distribution of forested areas (Fig. $4 \mathrm{~A}$ ). One of the most evident is that once all the fragments that are unable to maintain a part 
(A) Whole area

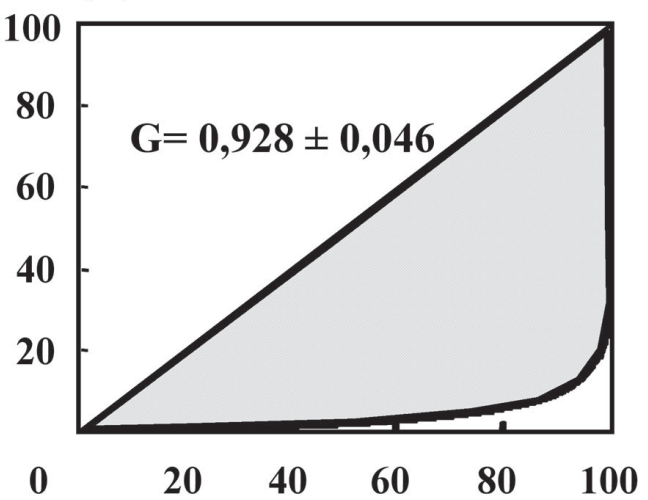

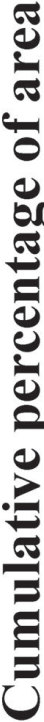

(C) $331-660 \mathrm{~m}$

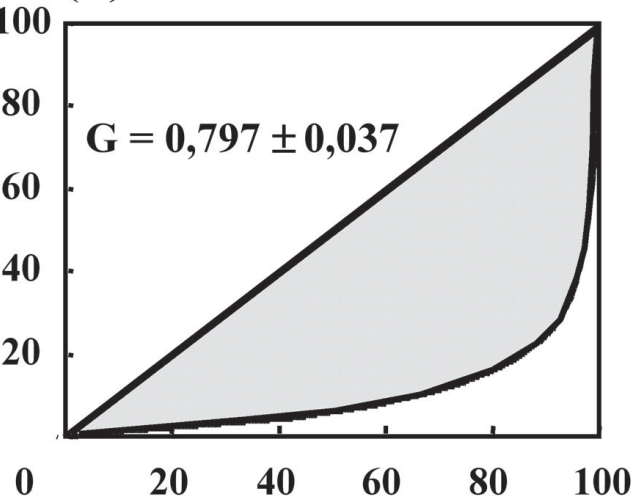

(E) $991-1,320 \mathrm{~m}$

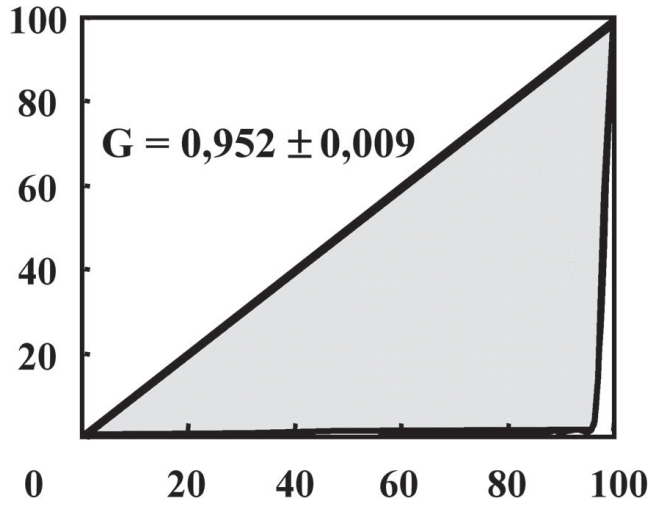

(B) 0-330 m

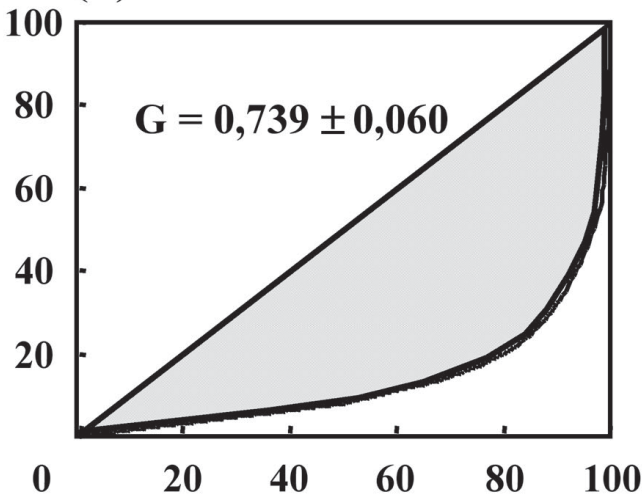

(D) $661-990 \mathrm{~m}$

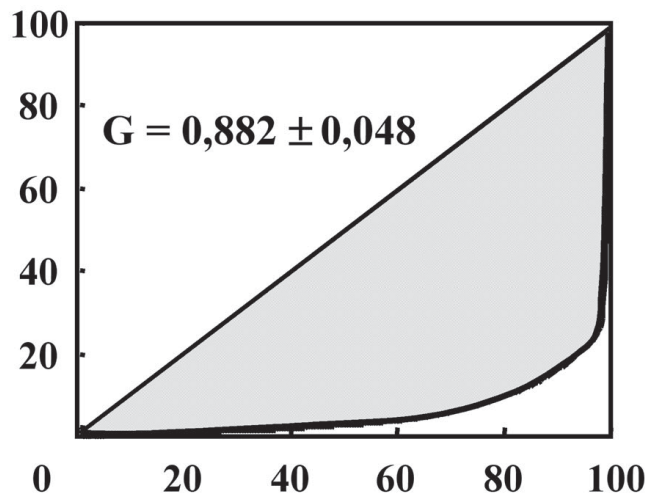

(F) 1,321-1,650 m

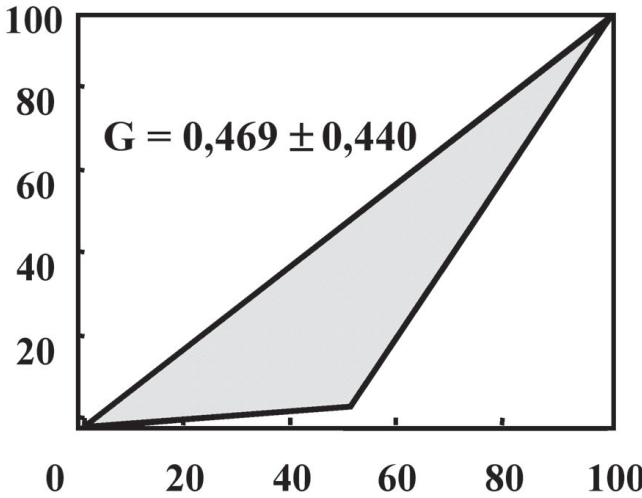

\section{Cumulative percentage of fragments}

Fig. 3: Lorenz curves describing area inequalities among forest fragments. The extent of the shaded area indicates the magnitude of the departure from perfect equality and is reflected in the Gini coefficient $(\mathrm{G})$ [ \pm standard deviation]. Panel (A) corresponds to the complete study area and panels (B)-(F) represent each of the altitudinal bands.

Curvas de Lorenz que describen la desigualdad en el área de los fragmentos. El tamaño del área sombreada indica la magnitud del desvío de una distribución perfectamente equitativa y corresponde al valor del coeficiente de Gini $(\mathrm{G})[ \pm 1$ desviación estándar]. La parte (A) corresponde el área completa y (B)-(F) corresponden a los diferentes pisos altitudinales. 


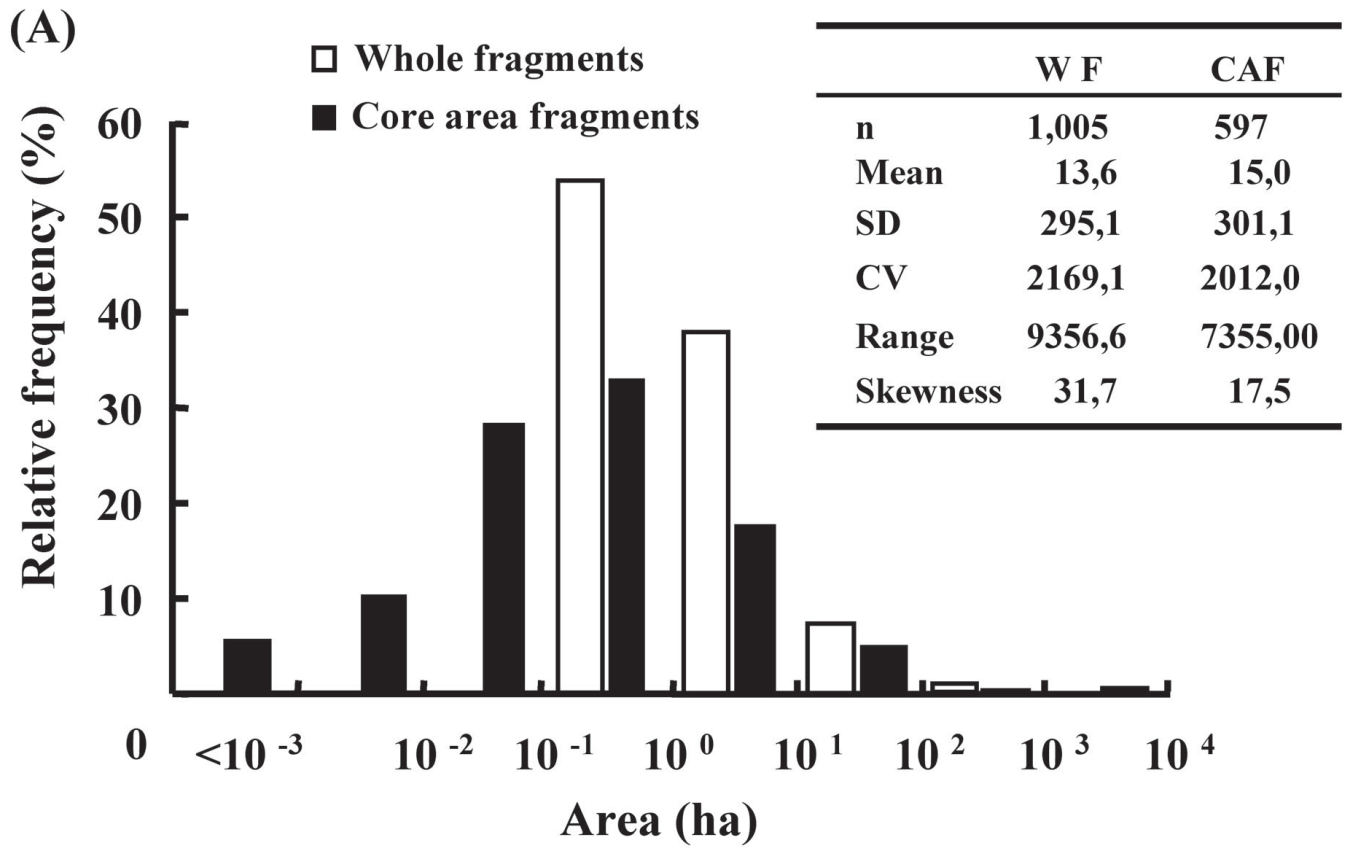

(B)

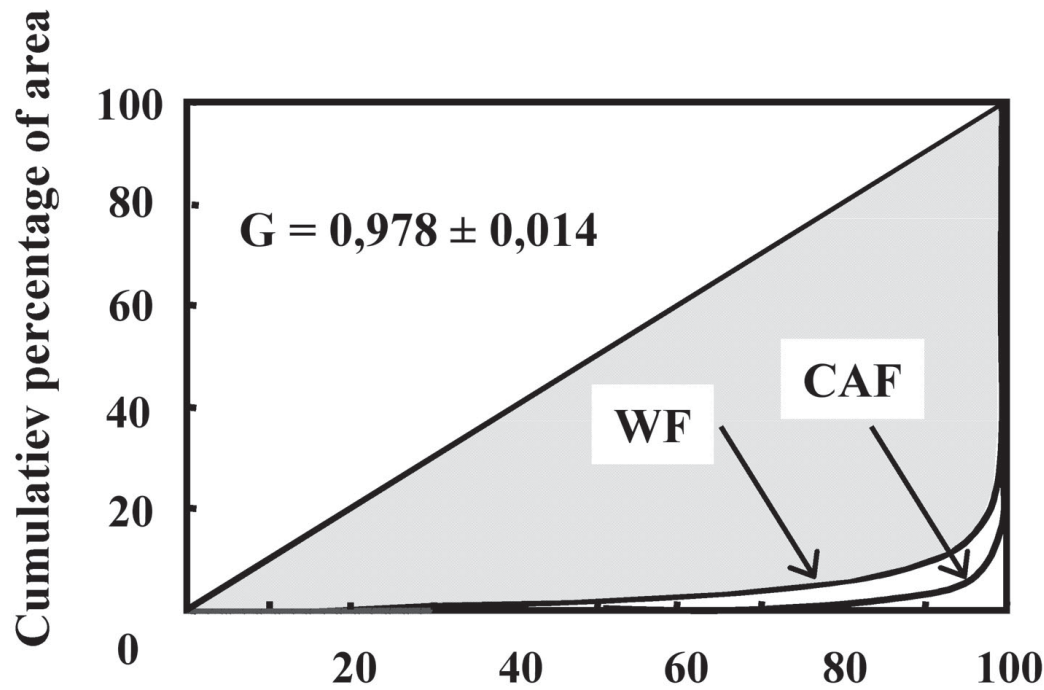

Cumulative percentage of fragments

Fig. 4: (A) Frequency-distribution of whole fragments (i.e., ignoring edge effects) (empty bars) and of core-area fragments (shaded bars). Numbers in the X-axis indicate the upper class limit; the first class includes areas $\leq 10^{-3}$ ha. The insert shows descriptive statistics of both distributions; (B) Lorenz curves corresponding to whole fragments (upper) and core areas (lower), the value of $\mathrm{G}[ \pm 1$ standard deviation] corresponds to the latter. Shaded area corresponds to departure from perfect equality.

(A) Distribución de frecuencias de las áreas de los fragmentos (ignorando el efecto de borde) (barras blancas) y áreas núcleo (barras negras). Los números en el eje de las X indican el límite superior de la clase; la primera clase incluye las áreas $\leq 10^{-3}$ ha. El recuadro muestra la descripción estadística de ambas distribuciones. (B) Curvas de Lorenz correspondientes a los fragmentos enteros (curva superior) y a las áreas núcleo (curva inferior). El valor de G $[ \pm 1$ desviación estándar] corresponde a las áreas núcleo. El área sombreada indica el grado de contraste con respecto a la máxima equidad. 
of its area free of such effect (heretofore corearea) are discarded, the number of fragments dramatically falls from 1,005 to 597 (see insert in Fig. 4). Furthermore, the shape of the frequency-distribution was also modified in a number of ways. The highest value of the distribution decreased by $21 \%$, moving from 9,356 to 7,354 ha. The lowest value also changed, passing from nearly 0.25 ha to almost 0 ha, and creating a previously non-existing left tail of the distribution (Fig. 4A). The contraction of the range led to an almost $50 \%$ reduction of the skewness (see insert in Fig. 4). The median values were more sensitive to qualitative/quantitative changes in the frequency-distribution, showing an $83 \%$ decrease, while mean values showed a slight change, only of $10 \%$. Nevertheless, a considerable amount of variation remains in the frequency distribution of core-area fragments (Fig. 4A). The consideration of this edge effect resulted in an even more flattened Lorenz curve than the corresponding to whole fragments (cf. Figs. 3A and 4B). In accordance with this effect on the Lorenz curve, the value of $\mathrm{G}$ experienced an increase of $5 \%$ passing from 0.928 to 0.978 , almost reaching the maximum value of 1,0 (highest inequality). These changes arise as a consequence of the remarkable reduction in core area experienced by small/ medium fragments, the consequent generation of very small core areas, and the relatively slight impact on the largest fragment. This reduces the contribution to total forest area due to most of the fragments and exacerbates the size contrast among fragments in the opposite extremes of the distribution.

The incorporation of an edge effect of $60 \mathrm{~m}$ leaves a total of 633 fragments, a number larger than the one produced by an edge effect of 30 $\mathrm{m}$. This situation is the result of a more intense pulverization of formerly larger fragments. Nevertheless, median size of fragments shifted from an original value of 0.89 ha to a value of 0,11 ha and the size of the largest fragment diminished from 9,356 ha to 5,243 ha, a $44 \%$ reduction. In comparison, the incorporation of an edge effect of $100 \mathrm{~m}$ has extreme effects on both the number of fragments and on the size of the largest fragment. Thus, the number of fragments falls to 224 (a $78 \%$ reduction) and the size of the largest fragment diminishes to 3,814 ha (a reduction of $59 \%$ ). In contrast, median size reached a value of 0.20 ha.

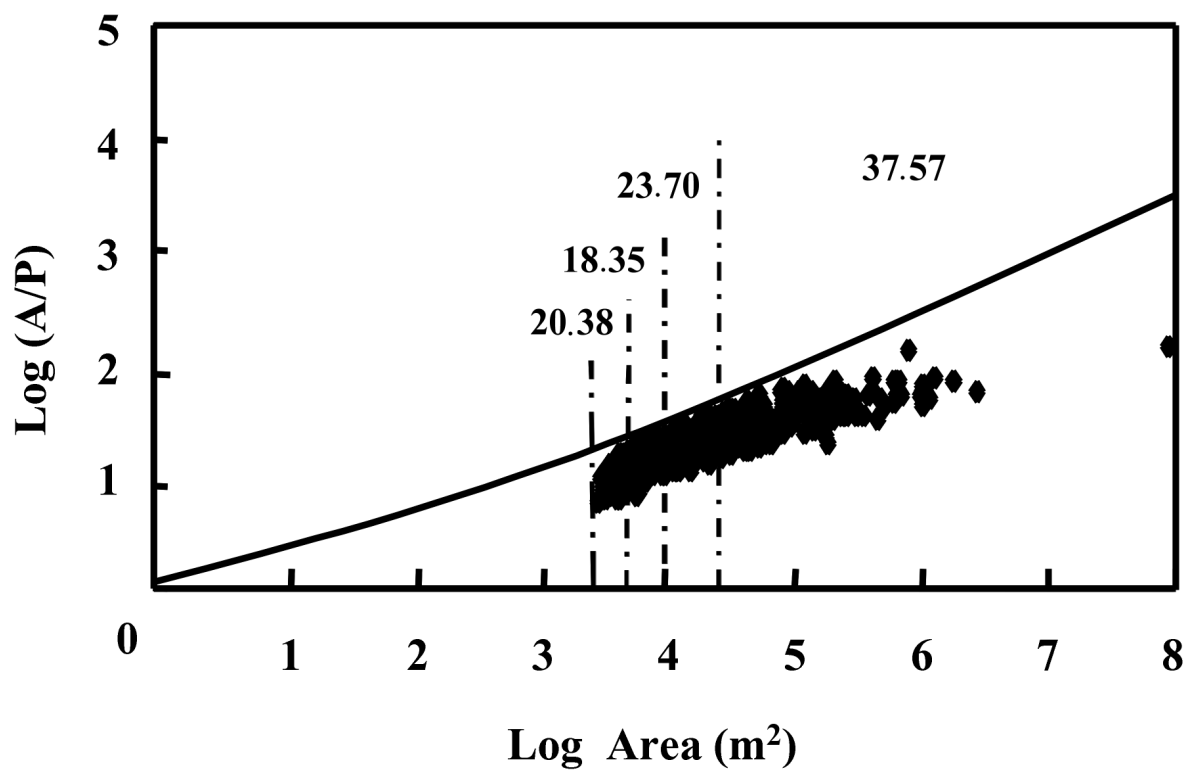

Fig. 5: Plot depicting the departure of the observed A/P fragment ratios from that of circles with equivalent areas (diagonal line). Numbers represent percent departure from expected for circular shapes, grouped per quartile.

Descripción de la magnitud del desvío de los cocientes A/P de los fragmentos con respecto a los correspondientes a círculos con la misma área. Los números representan el porcentaje del desvío total que corresponde a cada cuartil. 


\section{Fragment shapes}

The $\mathrm{A} / \mathrm{P}$ ratios of the fragments grouped in each of the first three quartiles of the frequency-distribution have a relatively low departure from the points on the diagonal in Figure 5, corresponding to $\mathrm{A} / \mathrm{P}$ ratios for circles with the same area. Deviations of fragment $\mathrm{A} / \mathrm{P}$ ratios from the corresponding ratios for equivalent circles in the first three quartiles vary between 18.4 and $23.7 \%$. In contrast, A/P ratios for fragments belonging to the fourth quartile show a larger deviation (Fig. 5 ), with an overall departure of $37.6 \%$. This means that the $25 \%$ largest fragments deviate relatively more from their corresponding circular fragments than fragments belonging to the first three quartiles (i.e., of the smaller size classes).

\section{Fragment isolation}

The number of fragments decreases with distance from the largest remnant forest tract (Fig. 6). Although the distance interval that individually holds the greater percentage of fragments (i.e., $16.4 \%$ ) is that between 0 and $500 \mathrm{~m}$, the majority of the remaining fragments lies further than $500 \mathrm{~m}$ away from the largest remnant tract. Such isolation of fragments is further exacerbated by the existence of a negative relationship between average fragment size and distance interval (Spearman correlation, $\mathrm{r}=-0.46, \mathrm{P}=0.019, \mathrm{n}=26$ ). On a larger spatial scale it is conceivable that the depicted level of isolation of forest fragments may change, in particular for the fragments laying at the lower right corner of the study area (Fig. 1 and 2), due to the proximity of another relatively large forest fragment (the Santa Marta volcano) falling outside the study area. However, given that the largest fragment in this study and the Santa Marta volcano lie nearly equidistant from the above-mentioned fragments, we do not expect a significant modification of this result.

Relationship between elevation and distribution of remnant forest and fragments

The patterns of land use in the region have led to a distinctive pattern of distribution of the remnant forest area in relation to altitude (Fig. 7). The area that lies below $660 \mathrm{~m}$, comprising $76 \%$ of the whole study area, only retains 34.3 $\%$ of the forested area. In comparison, the study area lying above $990 \mathrm{~m}$, which represents just $7.3 \%$ of the whole study area, holds $35.1 \%$ of the extant forested area. A remaining $30.6 \%$ of the current forested area lies on the interval of 661-990 m (Fig. 7). This fact implies that the forest coverage in the lowlands has been

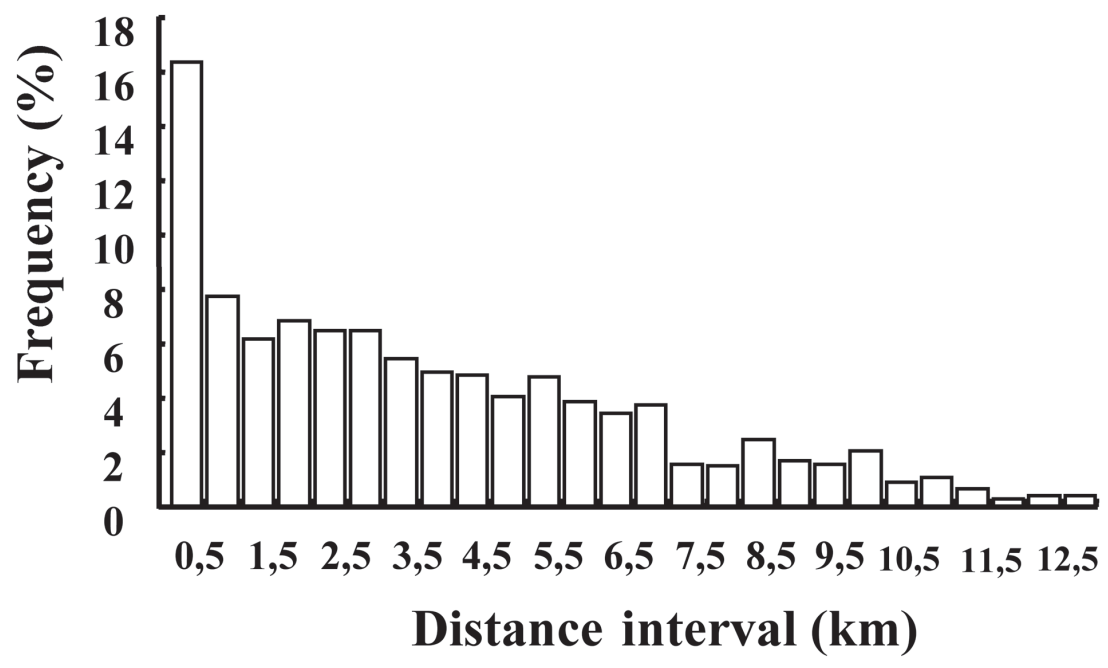

Fig. 6: Frequency distribution of forest fragments in the study area according to their distance to the largest remnant forest tract $(n=1,002)$.

Distribución de frecuencias de los fragmentos de acuerdo a su distancia con respecto al remanente de bosque más grande (n =1.002). 


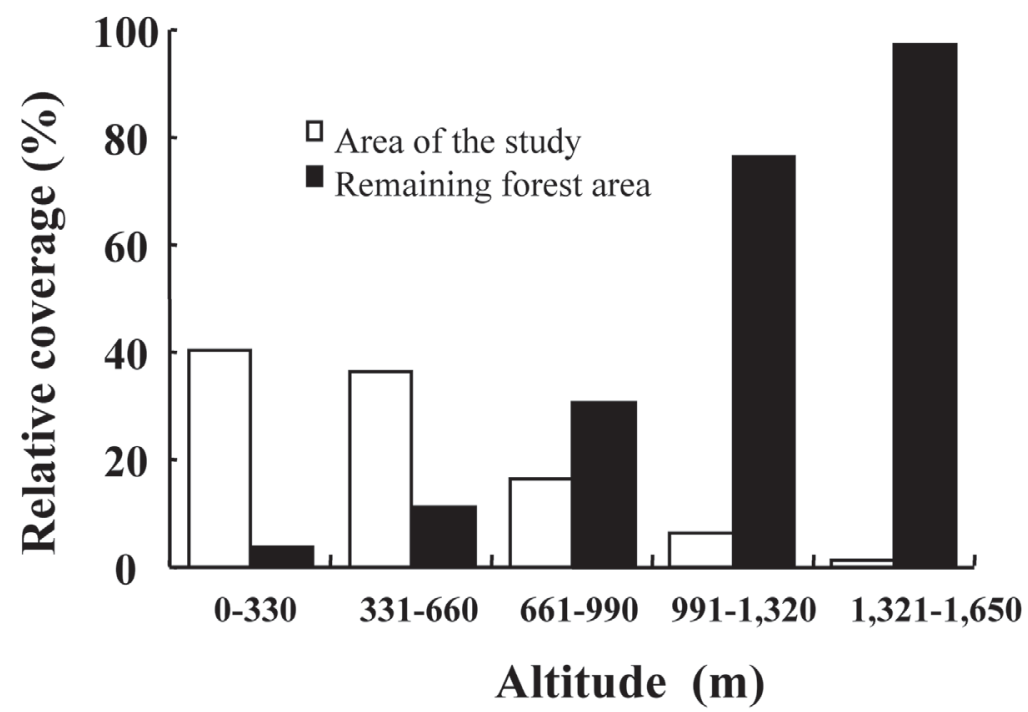

Fig. 7: Relative distribution of the study area by altitudinal levels (empty bars) and the percent coverage of remaining forest area in each of the corresponding altitudinal levels (shaded bars).

Distribución relativa del área de estudio por piso altitudinal (barras blancas) y el porcentaje de cobertura de bosque correspondiente (barras negras).

largely eradicated. Moreover, looking at the extremes of the elevation gradient, it is striking that the area laying above $1,320 \mathrm{~m}$ has almost full-forest coverage $(97.3 \%)$, while the area below $330 \mathrm{~m}$ retains less than $2 \%$ of its surface covered by forest (Fig. 7). The contrasting patterns of relative coverage depicted in Figure 7 are reflected in the negative relationship between available terrain to be potentially covered by forest and altitude (Spearman correlation, $\mathrm{r}=-1.0, \mathrm{P}<0.001, \mathrm{n}=5$ ) and from the positive relationship between altitude and proportion of actual forest coverage (Spearman correlation, $\mathrm{r}=1.0, \mathrm{P}<0.001, \mathrm{n}=5$ ). This results from the fact that only the most inaccessible, topographically complex areas have escaped deforestation.

The Gini coefficient and the Lorenz curve were sensitive to variation in forested area among fragments across the altitudinal gradient (Fig. 3B-F). The Gini coefficient shows an increasing tendency with a peak at the interval 991-1,320 m (i.e., 0.9525) (Fig. 3E), followed by a considerable decrease at the highest elevation (0.4692) (Fig. 3F). Such altitudinal tendency is reflected in the Lorenz curve, which shows an increasing reduction of the area under the curve up to $1,320 \mathrm{~m}$, followed by a noticeable increase in the highest elevation. The contrast between the two extreme data points (Fig. 3E versus Fig. 3F) stems from the fact that at the 991-1,320 altitudinal band one single "fragment", out of a total of 27 , accumulates close to $96 \%$ of the total forested area available in such interval. However, more important than this is the absolute size variation: the one largest fragment is ca. 4,800 times larger than the other ones. On the other hand, the lowest value of $G$ at the highest elevation is a consequence of the existence of just two fragments within this altitudinal interval. In this case, although the largest fragment shows a similar, $97 \%$ monopolization of area, its contrast with the other fragment is only 31 -fold. Thus, the lowest value of fragment size inequality corresponds to the altitudinal belt that holds the lowest absolute area of remnant forest (cf. Fig. 7).

\section{DISCUSSION}

The picture delineated by our forest map, the Lorenz curve, and the Gini coefficient indicate that the remaining forest in Los Tuxtlas represents a heavily fragmented landscape in which an archipelago of forest islands are immersed in a sea of cattle grasslands. Even when the map provides a dramatic pictorial view of the current spatial configuration of the 
remnant vegetation, the Gini coefficient provides a quantitative indicator of the image that, in addition, will be readily comparable to that obtainable from areas subjected to the same analysis. Quantitative descriptors such as $\mathrm{G}$ can provide a statistic that complements the widely used deforestation rate which, useful and conventional as it is, does not convey information on the patterns of fragmentation. To the extent that we incorporate descriptors of this kind as widely as possible, our overall perception of the conservation state of tropical forests can be more realistic.

In the case of Los Tuxtlas, our analysis shows that forests fragments fall into one of two contrasting categories: (A) that represented by a few relatively large fragments and (B) that constituted by a very large amount of peripheral, small fragments, individually retaining a very low proportion of the remaining forest. As a consequence of this pattern, an overwhelming majority of the forest fragments in Los Tuxtlas falls well below the sizes in which significant declines in the abundance and species richness of understory birds, butterflies and dung beetles in other tropical forests have been documented (Klein 1989, Newmark 1991, Daily \& Ehrlich 1995). In particular, forest fragments where howler monkeys (Aloautta palliata) can be found in Los Tuxtlas (Estrada et al. 1999) are on average more than 40- times larger than the median fragment size (0.89 ha). An additional and more general picture of the impact of fragmentation in Los Tuxtlas on the non-volant mammalian fauna can be gained through the comparison of current fragment sizes and the inferred habitat-area requirements of such fauna. If we use the published average densities of Neotropical forest mammals (Robinson \& Redford 1989) we find that 26 selected species whose historical occurrence has been reported for Los Tuxtlas, would not be able to accommodate a population with a minimum size of 50 individuals (sensu Soulé 1980) in fragments of the median size we documented for Los Tuxtlas. Moreover, according to this comparison even the largest forest fragment in our study area (9.356 ha) would be insufficient to support such minimum populations of two felids (jaguar and puma) and the tapir. Empirical support for these expectations is provided by field studies that have documented a contemporary impoverishment of the nonvolant mammalian fauna in our study area, particularly the medium/large animals whose habitat-area requirements are larger (Dirzo \& Miranda 1991b, Estrada et al. 1994).

An additional factor that may exacerbate biological impoverishment in forest fragments in Los Tuxtlas is isolation by distance to sources of inmigrants. Its is known that several groups of forest organisms are reluctant to cross open areas as short as $100 \mathrm{~m}$, including euglossine bees, understory birds and dung beetles (Powell \& Powell 1987, Klein 1989, Bierregaard \& Dale 1996). In Los Tuxtlas it has been documented that forest fragments in which monkeys are present have a mean distance to other forested sites of $166 \mathrm{~m}$, while fragments in which monkeys are absent have a mean distance of $462 \mathrm{~m}$ (Estrada et al. 1999). Our documented negative correlation between distance to the largest fragment and average fragment area may exacerbate isolation and therefore the vulnerability of populations of several species inhabiting such fragments. In addition, the predominant grassland matrix where most of the fragments are immerse appears to determine the movement of species of dung beetles and non-volant mammals, as suggested by the consistent poor representation of these animals in pastures (Estrada et al 1994, Estrada et al. 1999). In comparison, other animals such as bats show a more similar species composition and abundance between large and small forest fragments (Estrada \& Coates-Estrada 2002) suggesting that they are less susceptible to fragmentation. Evidently, attributes such as mobility, home range and tolerance to contrasting physical environments determine the vulnerability of animals to fragmentation (Estrada \& Coates-Estrada 2002).

From a botanical standpoint, while studies in some tropical forests indicate that small forest remnants may retain a considerable proportion of their original number of plant species for some time (Turner et al. 1994), evidence indicates that, in the long run, most of the plant communities in small forest fragments $(\sim 1 \mathrm{ha})$ tend to become impoverished due to the over-dominance of a subset of their species (Leigh et al. 1993, Turner et al. 1996, Asquith et al. 1997). The ecological consequences of fragmentation on plants is an aspect that 
currently is being investigated at Los Tuxtlas.

The effects of fragmentation may be exacerbated by a series of edge-related effects. Depending on the distance of penetration of the relevant variables, incorporation of such effects will, in the first place, reduce "effective" fragment size and number and, consequently, overall habitat area and distribution. In our case, this situation is illustrated by the dramatic reduction in the number of fragments (from 1005 to 597) and an increase of the Gini coefficient (from 0.928 to 0.978 ) resulting from the application of the estimated penetration distance, $30 \mathrm{~m}$, of microclimatic disruption. Nevertheless, penetration distances will vary depending on the variables of interest. Laurance (2002) indicates that penetration distances in Amazonia range from $10 \mathrm{~m}$ to 400 $\mathrm{m}$ and thus fragment effective size, $\mathrm{G}$, and spatial distribution will vary too. Our exercise application with penetration distances of $60 \mathrm{~m}$ as is the case of edge effects on lower canopyfoliage density, or $100 \mathrm{~m}$, as is the case of effects on abundance and diversity of leaf-litter invertebrates (Laurance 2002) yielded even more dramatic changes in the number of effective fragments and fragmentation parameters. Thus, the ecological effects of edge will depend on the variable of interest. In Los Tuxtlas, for example, a 30-m edge effect significantly affect the rates of leaf pathogenic infection by fungi (R. Dirzo, unpublished. data), as such fungi are highly susceptible to changes in temperature and humidity. According to the literature, ecological effects on variables such as foliage density, or on leaflitter invertebrates are to be expected by penetration distances of 60 and $100 \mathrm{~m}$, respectively. Furthermore, in our case even the largest fragments are likely to remain susceptible to some edge effects, given the considerable departure from the circular shape we detected in such fragments in this site.

A salient aspect revealed by the spatial configuration of remnant forest in the study area is that the intensive habitat transformation that this region has experienced has not proceeded with a homogeneous pace throughout the landscape. Instead, it has had a particularly strong impact on the lowlands, confining most of the forest remnants to the hilltops. Thus, the remaining vegetation does not constitute a representative sample of the original diversity of habitat types. Even when this is a logical, expected result, the magnitude of such conservational bias, and the detailed quantification of the spatial reconfiguration of forests are aspects that may provide useful insights in the case of topographically complex areas. For example, our expectation that fragment size inequality would monotonically decrease with elevation was not supported by the data. Instead, we found an increasing trend followed by a dramatic fall only in the highest elevation. The values of the Gini coefficient at the lowland sites $(0-330)$ and at the intermediate elevation (331-660) were rather high (0.739 and 0.797 , respectively), reflecting a considerable fragmentation of the area at these elevations. On the other hand, the highest $G$ value at the elevation 991-1,320 m, where the number of fragments is small (27), is explained by the fact that there is a single large fragment that dramatically contrasts with the few, very small, vegetation patches also present at this elevation. In contrast, the lowest inequality value $(0.469)$ observed at the highest elevation, arises from the fact that fragmentation is minimal in a very inaccessible area that, albeit of small size (ca. $0.87 \%$ of the total study area), retains a very high proportional forest coverage. Yet the existence of one single small fragment adjacent to the continuous forest here makes the inequality value to be of relatively intermediate magnitude (0.469). If such a fragment (which accounts for only $3 \%$ of the forest area at this elevation) were removed from the analysis then fragmentation would be absent here, thus supporting our initial expectation of a negative relationship between site accessibility and fragmentation.

Our evaluation of remnant forest distribution as a function of elevation has the caveat that the altitudinal belts were chosen arbitrarily and this may lead to the generation of artificial fragmentation patterns. However, the observed distribution of remaining forest and its fragmentation in relation to elevation reflects the existence of a considerable disruption in the availability of habitat types. The consequences of such ecological bias warrant further investigation in this and other tropical sites with comparable topographic complexity. Nevertheless, one can anticipate that the seasonal, altitudinal migrations known 
in some tropical forests birds and Lepidoptera (see González et al. 1997) are likely to be truncated in Los Tuxtlas and other sites with similar patterns of fragmentation.

Our analysis of forest coverage and the quantitative description of fragmentation in Los Tuxtlas provide some baselines for conservation and restoration planning, as well as the subsequent monitoring of the effects of such activities. In addition to the obvious conservation of the remaining vegetation, restoration activities, especially in the lowlands, should be undertaken as soon as possible. In particular, restoration efforts should be directed to reestablish forest continuity along the lowlands in a southeasterly direction (see Fig. 2). This is necessary in order to favor connectivity of the largest forest tract of our study area with the other large tract of remaining forest in the region, the Santa Marta volcano (see description of Study area). Furthermore, our digital map (Fig. 2) suggests the specific remnants that would have to be connected to provide the greatest effect of continuity, as assessed by the greatest reduction in the Gini coefficient. Such exercises may be undertaken first by computer simulations to define the greatest impacts on $G$ and then, followed by on-site programs of substitution of current activities (cattle grazing) by fencing of corridors and/or replacement by agroforestry practices that provide a more suitable habitat for native plants and animals. The benefits of a program like this can be compared with other targeted efforts using the fragmentation parameters we proposed here as guidelines. In general, once the on-site programs are undertaken, the fragmentation parameters can be used in the assessment and monitoring of the effectiveness of the deployed efforts.

In a larger context, the extensive fragmentation we observed at Los Tuxtlas results of global relevance, given the fact that this area constitutes the extreme northerly distribution of tropical rain forest in the Americas (Dirzo \& Miranda 1991a). Our study provides a diagnostic analysis that makes it evident that, in addition to the dramatic loss of forest area (see Dirzo \& García 1992), fragmentation has affected the region to a considerable extent. This calls for urgent conservation and restoration measures to be taken if we are to prevent a geographic contraction of the natural distribution of this ecosystem on the continent.

Finally, by taking advantage of the increasing accessibility to remote sense imagery and of the availability of tools to analyze it, and including fragmentation parameters like the ones we employed in this study, we may gain a more realistic perception (i.e., beyond the mere estimates of deforestation rates) of the current threats to tropical and global biodiversity.

\section{ACKNOWLEDGEMENTS}

We thank Fernando Rosas and Armando Aguirre for their assistance in the field. William Laurance read a previous draft and offered valuable comments. Martin Ricker allowed us to use his digital aerial photographs from Los Tuxtlas. EM was supported by a doctoral fellowship from CONACyT and DGEP-UNAM. A research period at the CCBStanford for EM was made possible by the help of Carol L. Boggs and the financial support from the Packard Foundation. Support to RD for field work was also provided by the Packard Foundation and by CONACYT.

\section{LITERATURE CITED}

ACHARD F, HD EVA, H-J STIBIG, P MAYAUX, J GALLEGO T RICHARDS \& J-P MALINGREAU (2002) Determination of deforestation rates of the world's humid tropical forests. Science 297: 9991002.

ASQUITH NM, SJ WRIGHT \& MJ CLAUSS (1997) Does mammal community composition control recruitment in Neotropical forests? Evidence from Panama. Ecology 78: 941-946.

BIERREGAARD RO \& VH DALE (1996) Islands in an ever changing sea: the ecological and socioeconomic dynamics of Amazonian rain forest fragments. In: Schelhas J \& R Greenberg (eds) Forest patches in tropical landscapes: 187-204. Island Press, Washington, District of Columbia, USA.

BORGES R M (2000) The anatomy of fragmentation. Journal of the Indian Institute of Sciences 80: 601608.

CLARK LABS THE IDRISI PROJECT. IDRISI 32 (1999) Clark Labs, the Idrisi Project. Worcester, Massachusetts, USA.

CONGALTON RG \& RA MEAD (1983) A quantitative method to test for consistence and correctness in photointerpretation. Photogrammetric Engineering and Remote Sensing (USA) 52: 223-227.

DAILY G \& PR EHRLICH (1995) Preservation of biodiversity in small rainforest patches: rapid evaluation using butterfly trapping. Biodiversity and Conservation 4: 35-55. 
DIRZO R (2001) Tropical forests. In: Chapin III, FS, OE Sala \& E Huber-Sannwald (eds) Global biodiversity in a changing environment, scenarios for the $21 \mathrm{st}$ century: 251-276. Springer-Verlag, New York, New York, USA.

DIRZO R \& A MIRANDA (1991a) El límite boreal de la selva tropical húmeda en el continente americano: contracción de la vegetación y solución de una controversia. Interciencia 16: 240-247.

DIRZO R \& A MIRANDA (1991b) Altered patterns of herbivory and diversity in the forest understory: a case of study of the possible consequences of contemporary defaunation. In: Price PW, TM Lewinsohn, GW Fernandes \& WW Benson (eds) Plant-animal interactions: evolutionary ecology in tropical and temperate regions: 273-287. John Wiley \& Sons, New York, New York, USA.

DIRZO R \& MC GARCÍA (1992) Rates of deforestation in Los Tuxtlas, a Neotropical area in southeast Mexico. Conservation Biology 6: 84-90.

DIRZO R, E GONZÁLEZ \& RC VOGT (1997) Introducción general. In: González E, R Dirzo \& RC Vogt (eds) Historia natural de Los Tuxtlas: 3-6. CONABIO, Instituto de Ecología-UNAM, Instituto de Biología-UNAM, Mexico City, México.

DUCLOS J-Y, A ARAAR \& C FORTIN (2002) DAD4. 2: Distributive analysis. Université Laval. Québec, Canada. Available from: http:// www.mimap. ecn.ulaval.ca/

EASTMAN RJ (1999) Guide to GIS and image processing. Clark Labs, Clark University, Worcester, Massachusetts, USA.

ELKIE PC, RS REMPEL, AP CARR, R KUSHNERIUK \& J ELLIOT (1999) Patch analyst 2.2. Sustainable Forest Management Network, and Center for Northern Forest Ecosystem Research. University of Alberta, Canada. Available from: http:// flash.lakeheadu.ca/ rrempel/patch/

ENVIRONMENTAL SYSTEMS RESEARCH INSTITUTE INC, ESRI, (2000) ArcView Gis 3.2a. ESRI Redlands, California, USA.

ESTRADA A, R COATES-ESTRADA \& D MERITT (1994) Non flying mammals and landscape changes in the tropical rain forest region of Los Tuxtlas, Mexico. Ecography 17: 229-241.

ESTRADA A, A ANZURES \& R COATES-ESTRADA (1999) Tropical rainforest fragmentation, howler monkeys (Alouatta palliata) and dung beetles at Los Tuxtlas Mexico. American Journal of Primatology 48: 253-262.

ESTRADA A \& R COATES-ESTRADA (2002) Bats in continuous forest, forest fragments and in an agricultural mosaic habitat-island at Los Tuxtlas Mexico. Biological Conservation 103: 237-245.

FAHRIG L (2003) Effects of habitat fragmentation on biodiversity. Annual Review of Ecology and Systematic 34: 487-515.

FAO (1993) Forest resources assessment 1990: tropical countries. FAO (Food and Agriculture Organization) Forestry paper 112. (Food and Agriculture Organization) FAO, Rome.

FAO (2001) State of the world's forest 2001. FAO, Rome

GONZÁLEZ E, R DIRZO \& RC VOGT (eds) (1997) Historia natural de Los Tuxtlas. CONABIO, Instituto de Ecología-UNAM, Instituto de BiologíaUNAM, Mexico City, Mexico. xiv+647 pp.

GUEVARA S, J LABORDE, D LIESENFELD \& O BARRERA (1997) Potreros y ganadería. In: González E, R Dirzo \& RC Vogt (eds) Historia Natural de Los Tuxtlas: 43-58. CONABIO, Instituto de Ecología-UNAM, Instituto de Biología-UNAM, Mexico City, México.

GUSTAFSON EJ (1998) Quantifying landscape spatial pattern: what is the state of the art? Ecosystems 1: 143-156.

IBARRA-MANRÍQUEZ G, M MARTÍNEZ-RAMOS, R DIRZO \& J NUÑEZ-FARFÁN (1997) La vegetación. In: González E, R Dirzo \& RC Vogt (eds) Historia natural de Los Tuxtlas: 61-85. CONABIO, Instituto de Ecología-UNAM, Instituto de Biología-UNAM, Mexico City. México.

KAISER J (2002) Satellites spy more forest than expected. Science 297: 919.

KLEIN DR (1989) The effects of forest fragmentation on dung and carrion beetle (Scarabinae) communities in central Amazonia. Ecology 70: 1715-1725.

LARSON KC \& TG WHITHAM (1997) Competition between gall aphids and natural plant sinks: plant architecture affects resistance to galling. Oecologia 109: 575-582.

LAURANCE WF \& RO BIERREGAARD Jr (1997) A crisis in the making. In: Laurance WF \& RO Bierregaard $\mathrm{Jr}$ (eds) Tropical forest remnants: xixv. Chicago Press, Chicago, Illinois, USA

LAURANCE WF, TE LOVEJOY, HL VASCONCELOS, EM BRUNA, RK DIDHAM, PC STOUFFER, C GASCON, RO BIERREGAARD, SG LAURANCE \& E SAMPAIO (2002) Ecosystem decay of Amazonian forest fragments: a 22-year investigation. Conservation Biology 16: 605-618.

LAWTON RO, US NAIR, RA PIELKE SR \& RM WELCH (2001) Climatic impact of tropical lowland deforestation on nearby montane cloud forests. Science 294: 584-587.

LEIGH EG, SJ WRIGHT, EA HERRE \& FE PUTZ (1993) The decline of tree diversity on newly isolated tropical islands: a test of a null hypothesis and some implications. Evolutionary Ecology 7: 76-102.

MATLACK GR (1994) Vegetation dynamics of the forest edge-trends in space and successional time. Journal of Ecology 82: 113-123.

MALHI Y \& J GRACE (2000) Tropical forests and the atmospheric carbon dioxide. Trends in Ecology and Evolution 15: 332-337.

NEWMARK WD (1991) Tropical forest fragmentation and the local extinction of understory birds in the eastern Usambara mountains, Tanzania. Conservation Biology 5: 67-78.

PERES CA (2001) Synergistic effects of subsistence hunting and habitat fragmentation on Amazonian forest vertebrates. Conservation Biology 15: 14091505.

POWELL AH \& GVN POWELL (1987) Population dynamics of euglossine bees in Amazonian forest fragments. Biotropica 19: 176-179.

RANTA P, T BLOM, J NIEMELA, E JOENSUU \& M SIITONENE (1998) The fragmented Atlantic rain forest of Brazil: size, shape and distribution of forest fragments. Biodiversity and Conservation 7: 385-403.

RICKETTS TH (2001) The matrix matters: effective isolation in fragmented landscapes. American Naturalist 158: 87-99.

RUIZ B (2003) Impacto de la fragmentación sobre los factores del ambiente físico y los patrones de herbivoría en plantas de la selva de Los Tuxtlas, Veracruz. B.Sc. Thesis, School of Sciences, Universidad Nacional Autónoma de México, México City, Mexico. v+ 97 pp.

SÁNCHEZ-AZOFEIFA A, RC HARRIS \& DL SKOLE (2001) Deforestation in Costa Rica: a quantitative 
analysis using remote sensing imagery. Biotropica 33: 378-384.

SAUNDERS DA, RJ HOBBS \& CR MARGULES (1991) Biological consequences of ecosystem fragmentation: a review. Conservation Biology 5: $18-32$

SILVA JMC \& M TABARELLI (2000) Tree species impoverishment and the future of the Atlantic forest of northeast Brazil. Nature 404: 72-74.

SKOLE DL \& C TUCKER (1993) Tropical deforestation and habitat fragmentation in the Amazon: satellite data 1978 to 1988 . Science 260: 1905-1910.

SLACK B \& J-P RODRIGUE (2002) Gini coefficient. In: Rodrigue J-P (ed) Transport Geography on the Web. Department of Economics \& Geography, Hofstra University, New York, USA. Available from: http://people.hofstra.edu/geotrans/eng/ch4en/ meth4en/ch4m1en.html/

SOTO M \& L GAMA (1997) Climas. In: González E, R Dirzo \& RC Vogt (eds) Historia natural de Los Tuxtlas: 7-23. CONABIO, Instituto de EcologíaUNAM, Instituto de Biología-UNAM, Mexico City.

SOULÉ ME (1980) Thresholds for survival: maintaining fitness and evolutionary potential. In: Soulé ME \& BA Wilcox (eds) Conservation biology: an evolutionaryecological perspective:151-169. Sinauer Associates, Sunderland, Massachusetts, USA.
TURNER IM (1996) Species loss in fragments of tropical rain forests: a review of the evidence. Journal of Applied Ecology 33: 200-209.

TURNER IM, HTW TAN, YC WEE, AB IBRAHIM, PT CHEW \& RT CORLETT (1994) A study of plant species extinction in Singapore: lessons for the conservation of tropical biodiversity. Conservation Biology 8: 705-712.

TURNER IM, KS CHUA, JSY ONG, BC SOONG \& HWT TAN (1996) A century of plant species loss from an isolated fragment of lowland tropical rain forest. Conservation Biology 10: 1229-1244.

VITOUSEK PM, HA MOONEY, J LUBCHENCO \& JM MELILLO (1997) Human domination of Earth ecosystems. Science 277: 494-499.

WEINER J (1986) How competition for light and nutrients affects size variability in Ipomea tricolor populations. Ecology 67: 1425-1427.

WEINER J \& OT SOLBRIG (1984) The meaning and measurement of size hierarchies in plant populations. Oecologia 61: 334-336.

WEINER J \& SC THOMAS (1986) Size variability and competition in plant monocultures. Oikos 47: 211222 .

WRI (World Resources Institute) (1990) World Resources 1990-1991. Oxford University Press, New York, New York, USA. 